\title{
HUBUNGAN PENGETAHUAN PERAWAT MENGENAI KELENGKAPAN DOKUMENTASI KEPERAWATAN
}

\author{
Pebi Septrian Sari \\ Email : febi.septrian03@gmai.com
}

\section{LATAR BELAKANG}

Keperawatan sebagai profesi yang bekerja dalam menentukan tindakan didasari pada ilmu pengetahuan serta memiliki keterampilan yang jelas dalam keahliannya dan mempunyai otonomi dalam kewenangan dan tanggung jawab dalam tindakan serta adanya kode etik dalam bekerjanya kemudian juga berorientasi pada pelayanan dengan melalui pemberian asuhan keperawatan kepada individu,kelompok, atau masyarakat (Hidayat,2011). Sebagai suatu profesi yang berdasarkan ilmu dan kiat keperawatan, dan berdasar pada kebutuhan objektif klien untuk mengatasi masalah klien, maka salah satu bagian yang penting dari asuhan keperawatan adalah dokumentasi perawatan.

Dokumentasi keperawatan adalah pencatatan setiap kegiatan asuhan keperawatan yang diberikan, kegiatan tersebut dilakukan oleh perawat sebagai tugas dan tanggung jawab setelah melakukan intervensi keperawatan. Dokumentasi keperawatan itu sangat penting untuk merencanakan, melaksanakan, dan mengevaluasi asuhan keperawatan. Oleh karena itu, jika kegiatan keperawatan ini tidak didokumentasikan dengan baik, akurat, dan obyektif dan lengkap serta sesuai dengan standar asuhan keperawatan maka sulit untuk membuktikan bahwa tindakan keperawatan telah dilakukan dengan benar( Gillies,2000; Carpenito,1999). Dokumentasi keperawatan dilakukan sejak awal pasien masuk atau dirawat sampai pasien pulang atau keluar dari rumah sakit.

Pengetahuan dalam pelaksanaan dokumentasi keperawatan ini harus dimiliki oleh profesi tenaga kesehatan yang paling utama adalah perawat. Seorang perawat harus membuat dokumentasi keperawatan secara lengkap dan jelas setelah pasien menerima pelayanan. Pada dasarnya perawat masih memiliki permasalahan, yaitu masih rendahnya tingkat pengetahuan terhadap pendokumentasian keperawatan. Pengetahuan ini yang menentukan tindakan perawat dalam memberi pelayanan, sehingga perawat yang punya pengetahuan akan lebih baik daripada perawat melakukan tindakan tanpa adanya pengetahuan. Maka pengetahuan ini sangat berpengaruh dalam membuat kelengkapan dokumentasi keperawatan. Pendokumentasian yang 
tidak lengkap akan memberikan kerugian bagi pasien karena informasi penting terkait perawatan dan kondisi kesehatannya terabaikan (Teytelmen,2002).

Selain itu, ketidaklengkapan dokumentasi keperawatan dipengaruhi oleh beberapa faktor, antara lain : Tingkat Pendidikan, pengetahuan, format asuhan keperawatan, motivasi, dan pengalaman kerja. Dokumentasi ini merupakan komunikasi yang tertulis untuk itu perawat diharapkan bisa menerapkan asuhan keperawatan dengan pendokumentasian yang benar.

\section{METODE}

Metode yang digunakan dalam penugasan ini dibuat adalah literatur review dengan cara menganalisis,dimana hasil analisis dilakukan dengan cara membandingkan atau mengamati dari berbagai text book, jurnal, e- journal dan berbagai sumber ilmiah lainnya yang berhubungan dengan pendokumentasian keperawatan. Adapun jurnal yang digunakan pada literatur review ini jurnal yang terbit 10 tahun terakhir .

\section{HASIL}

Dari kajian ini didapatkan hasil, kelengkapan pendokumentasian yang dilakukan perawat sebagian besar kurang dari $85 \%$ artinya sebagian besar masih belum lengkap 71,6\%, sedangkan yang sudah lengkap hanya $28,4 \%$. Presentase pendokumentasian yang dilakukan perawat meliputi paling besar pengkajian dan paling sedikit catatan perkembangan $66 \%$. Rerata kegiatan pendokumentasian yang dilakukan perawat sebesar $77 \%$. Bahwa faktor pengetahuan perawat sangat berpengaruh dalam pendokumentasian keperawatan karena akan menurunkan mutu pelayanan keperawatan dan perbaikan status kesehatan klien. Untuk meningkatkan pengetahuan perawat terhadap kelengkapan dokumentasi keperawatan, maka perlu adanya upaya-upaya untuk meningkatkan pengetahuan perawat dalam bentuk pelatihan maupun dalam bentuk pengetahuan lainnya.

\section{PEMBAHASAN}

Dokumentasi keperawatan merupakan bukti pencatatan dan pelaporan yang dimiliki oleh perawat dalam melakukan catatan keperawatan yang berguna bagi pasien, perawat dan tim kesehatan dalam memberikan pelayanan kesehatan dengan dasar komunikasi yang akurat lengkap secara tertulis dan dapat dipertanggung jawabkan perawat. Perawat harus memiliki tingkat pengetahuan yang cukup tentang pendokumentasian asuhan keperawatan yang meliputi pengkajian, diagnosa, intervensi, impelementasi, evaluasi,dan dokumentasi. 
Pengetahuan terkait dokumentasi keperawatan yang lengkap masih rendah. Hal tersebut bertentangan dengan penelitian Fizran dan Mamdy (2002) menyatakan bahwa tingkat pengetahuan berhubungan secara bermakna dengan kinerja perawat dalam pendokumentasian keperawatan. Dokumentasi keperawatan merupakan komponen yang paling penting secara keseluruhan dalam pelayanan pasien selain untuk memenuhi standar akreditasi rumah sakit. Faktor-faktor yang mempengaruhi dalam melakukan pendokumentasian asuhan keperawatan yaitu beban kerja perawat, pengetahuan perawat, pelatihan, motivaso perawat dalam bekerja dan sarana prasarana yang terdapat di rumah sakit untuk mengoptimalkan kesembuhan klien. Salah satu dari faktor ini adalah pengetahuan dan pelatihan. Pengetahuan perawat sangat diperlukan dalam pengisian dokumentasi secara benar dan lengkap.

Hasil penelitian didapatkan faktor yang paling dominanan terhadap kelengkapan pendokumentasian salah satunya adalah pelatihan. Pelatihan merupakan suatu kegiatan atau fungsi manajemen yang perlu dilakukan secara terus-menerus dan sangat penting dalam peningkatan kualitas dokumentasi asuhan keperawatan. Perawat yang pernah mengikuti pelatihan dengan kelengkapan pendokumentasian cenderung akan mendokumentasikan asuhan keperawatan secara lengkap. Hal ini juga sejalan dengan penelitian Lusianah(2008) menyatakan bahwa ada hubungan antara kualitas dokumentasi asuhan keperawatan dengan pelatihan, kualitas dokumentasi akan meningkat sebesar 1,60 kali pada perawat yang pernah pelatihan dibanding yang belum pernah pelatihan.

Pelatihan asuhan keperawatan dipengaruhi oleh beberapa faktor (soeprijadi, 2006) :

a. faktor pelatih, dengan menggunakan pelatih yang profesional

b. faktor peserta, pelatihan yang mempunyai rasa kebersamaan tinggi dilihat dari dinamika kelompok yang sangat mendukung kearah proses belajar mengajar

c. faktor metode pelatihan, metode yang tepat akan menimbulkan kegairahan belajar para peserta

d. faktor materi pelatihan yang disusun dengan baik akan menimbulkan ketekunan dari para peserta pelatihan.

Pada saat melakukan pendokumentasian juga dipengaruhi oleh perawat itu sendiri karena kurangnya kemampuan tidak tahu data apa saja yang harus diisi dan bagaimana cara mendokumentasikannya. Hal itu diakibatkan oleh pengetahuan dan pelatihan yang minim 
terhadap pendokumentasian. Selain itu, bagi perawat pentingnya pelatihan pendokumentasian ini sudah memberi dampak positif terhadap kinerja perawat terkhusus dalam melakukan pendokumentasian keperawatan. Dalam melakukan pendokumentasian perawat yang tidak lengkap juga dipengaruhi oleh beban kerja yang tinggi karena inilah yang mempengaruhi kinerja perawat dalam melakukan kegiatan pendokumentasian keperawatan.

Ketidaklengkapan pendokumentasian keperawatan akan menghasilkan informasi yang tidak tepat dan bersifat legal. Maka itu, setiap tenaga kesehatan terutama perawat yang memberikan pelayanan harus mengisi dokumentasi secara lengkap untuk menghindari hal-hal yang tidak diinginkan. Manfaat dokumentasi asuhan keperawatan ini apabila dikemudian hari ada kasus hukum yang berkaitan dengan pasien tertentu maka catatan asuhan keperawatan ini menjadi bukti yang sah terhadap tindakan yang dilakukan oleh perawat.

\section{PENUTUP}

\section{Kesimpulan}

Dokumentasi keperawatn ini merupakan bukti pencatatan dan pelaporan yang dimiliki oleh perawat dalam melakukan catatan yang berguna bagi pasien, perawat dan tim kesehatan lain dalam memberikan pelayanan kesehatan dengan dasar komunikasi yang akurat lengkap secara tertulis dan dapat dipertanggung jawabkan. Berdasarkan karakteristik perawat menunjukan bahwa kelengkapan pendokumentasian keperawatan berhubungan dengan pengetahuan dan pelatihan menunjukkan ada hubungan yang bermakna dalam kelengkapan pendokumentasian. Dan untuk meningkatkan pelatihan terhadap pendokumentasian keperawatan dapat dilakukan oleh perawat secara berkala.

\section{DAFTAR PUSTAKA}


Inayati, A. \& Sriyati. (2020). Tingkat Pengetahuan Dokumentasi Asuhan Keperawatan Terhadap Pelaksanaan Dokumentasi Asuhan Keperawatan di RS PKU Muhammadiyah Yogyakarta. Indonesian Journal of Hospitals Administration.Vol 3(1). 1-6

Widuri., Maryadi., \& Astuti, D, L. (2017). Hubungan Tingkat Pengetahuan Perawat Dengan Kepatuhan Melaksanakan Pendokumentasian ASKEP di Ruang Rawat Inap RS Jih Yogyakarta. MIKKI. Vol 05(01). 69-71

Mastini, P., Suryadhi, T,N., \& Suryani,A. (2015). Hubungan Tingkat Pengetahuan, Sikap, Beban Kerja Perawat dengan Kelengkapan Dokumentasi Asuhan Keperawatan di IRNA IGD RSUP Sanglah Denpasar. Public Health and Preventive Medicine Archive. Vol 3(1). 49-53

Nuryani, N., \& Susanti, D, D. (2014). Hubungan Pengetahuan Perawat Dengan Kelengkapan Dokumentasi Asuhan Keperawatan di RSUD dr. Soekardjo Kota Tasikmalaya. Jurnal manajemen Informasi Kesehatan Indonesia. Vol 3(1). 5-9

Simamora, R. (2009). Dokumentasi Proses Keperawatan.

Simamora, R. H., Purba, J. M., Bukit, E. K., \& Nurbaiti, N. (2019). Penguatan Peran Perawat Dalam Pelaksanaan Asuhan Keperawatan Melalui Pelatihan Layanan Prima. JPPM (Jurnal Pengabdian Dan Pemberdayaan Masyarakat). Vol 3(1). 25-31

Siswanto, H, L.M., Hariyati, S, T, Rr., \& Sukihananto. (2013). Faktor-faktor Yang Berhubungan Dengan Kelengkapan Pendokumentasian Asuhan Keperawatan. Jurnal Keperawatan Indonesia. Vol 16(02). 77-84

Mangole, E, J., Rompas, S., \& Ismanto, Y, A. (2015). Hubungan Perilaku Perawat Dengan Pendokumentasian Asuhan Keperawatan Di Cardiovaskular And Brain Center RSUP Prof.DR. R. D Kandou Manado. E-journal Keperawatan. Vol 3 (2). 1-9

Kimalaha, N., Mahfud., \& Anggraini, N, A. (2018). Pengetahuan dan Beban Kerja Perawat Berhubungan Dengan Kelengkapan Pendokumentasian Asuhan Keperawatan di Bangsal Penyakit Dalam dan Bedah. Indonesian Journal of Hospital Administration. Vol 1(2). 79-88

Noorkasiani., Gustina., \& Maryam, S, R. (2015). Faktor-faktor Yang Berhubungan Dengan Kelengkapan Dokumentasi Keperawatan. Jurnal Keperawatan Indonesia. Vol 18(1). 1-8 
Yanti, I, R., \& Warsito, E, B. (2013). Hubungan Karakteristik Perawat, Motivasi, Dan Supervisi Dengan Dokumentasi Proses Asuhan Keperawatan. Jurnal Management Keperawatan. Vol 1(2). 107-114

Supratti \& Ashriady. (2016). Pendokumentasian Standar Asuhan Keperawatan Di Rumah Sakit Umum Daerah Mamuju Indonesia. Jurnal Kesehatan Manarang. Vol 2(1). 44-51. 